\title{
12. SEDIMENTOLOGY OF PALYNOMORPHS AND PALYNODEBRIS IN CRETACEOUS CARBONACEOUS FACIES SOUTH OF VIGO SEAMOUNT
}

\author{
Daniel Habib, Queens College, Flushing, New York
}

\begin{abstract}
Palynological study of 94 samples representing the late Hauterivian-Cenomanian carbonaceous section at Site 398, DSDPIPOD Leg 47B, revealed major fluctuations in the abundance and distribution of palynomorphs. Three palynofacies were distinguished, based on the distribution of palynomorphs and palynodebris. The exinitic palynofacies is characterized by numerous specimens and species of sporomorphs to the almost total exclusion of dinoflagellate cysts and small acritarchs, and by structured palynodebris such as vascular plant cuticle and tracheids. It is considered to have been emplaced during times of high rates of sedimentation of land plant materials contributed from actively prograding deltas. The micrinitic palynofacies is characterized by abundant amorphous palynodebris in the form of small, apparently carbonized, opaque or semi-opaque carbonaceous particles and a palynoflora composed of fewer specimens dominated by Classopollis, bisaccates, and dinoflagellates. It represents the much diminished sedimentation of terrigenous vegetal materials, and was deposited by marine currents which concentrated those sporomorph types morphologically adapted for selective transportation. The xenomorphic palynofacies contains a palynoflora similar to that of the micrinitic facies, but is distinquished by an abundance of amorphous palynodebris composed of optically translucent particles which show safranin stain well. Palynomorphs may be rare or abundant in this facies.

The close correspondence between the sporomorph abundance and organic carbon curves indicates that the organic carbon composition of the more carbonaceous intervals of the investigated section is terrigenous and derived from land plants. The smaller carbonaceous content of the micrinitic facies may be the result of the much smaller contribution of land plant materials. The lack of a direct correspondence between the sporomorph assemblages and organic carbon composition in the xenomorphic facies suggests that factors other than, or additional to, the sedimentation of terrigenous plant materials were responsible for the carbonaceous composition of these sediments.
\end{abstract}

\section{INTRODUCTION}

Site 398 was drilled on Leg 47B in the Galician region near the Iberian Peninsula. Its purpose was to study the historical development of this continental margin since the time of separation of southern Europe from North America (Site Report, this volume).

Five holes were drilled at Site 398, located just south of the base of Vigo Seamount, between Portugal and Galicia Bank (Figure 1). Hole 398D was drilled in a water depth of 3890 meters, and penetrated the sea floor to a sub-bottom depth of 1740 meters. Recovery of 138 cores represents an almost continuously cored section ranging in age from late Hauterivian to Pleistocene. A detailed description of the lithology and sedimentary history of this section is given in the Site Report (this volume).
Hole 398D recovered an interval of highly carbonaceous sediments of late Hauterivian-Cenomanian age. The palynology of this part of the section was investigated for comparison of its stratigraphy with the palynostratigraphy published on DSDP samples from the western North Atlantic (Habib, 1977). The initial results published in this report indicate that the palynology of Hole 398D is different insofar as there are major fluctuations in the number of palynomorphs, and that the more palyniferous samples are characterized by the abundance of pteridophyte spores and gymnospermous pollen grains to the almost total exclusion of dinoflagellate cysts. Many of the spore species, especially those of striate schizaeaceous spores, are absent or rare in the Lower and Middle Cretaceous of the western North Atlantic. There is some comparison, however, with the palynomorph assemblages reported from the 


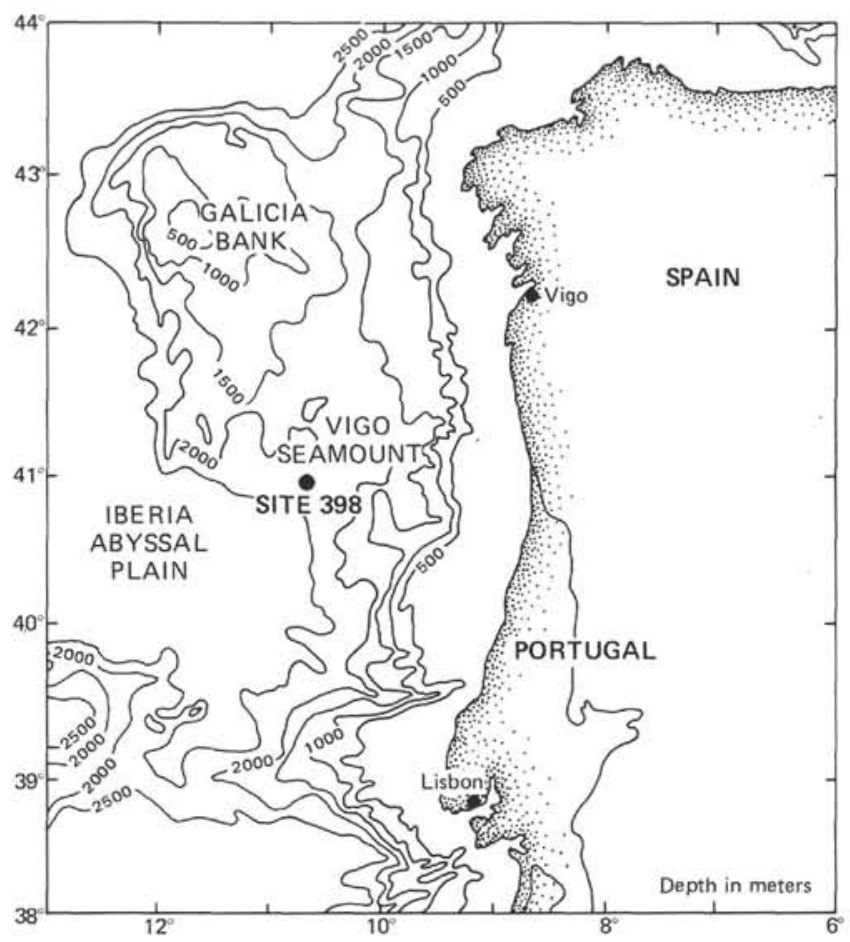

Figure 1. Geographic location of Site 398, south of Vigo Seamount.

Lower and Middle Cretaceous of the Grand Banks and Scotian Shelf off eastern Newfoundland (Williams, 1975; Williams and Brideaux, 1975).

The chronostratigraphic value of the palynomorphs in the late Hauterivian-Cenomanian part of the section for precise age dating is limited, due to the presence of intervals where palynomorphs are limited, and to the general paucity of dinoflagellate fossils. Thus, all references to the specific ages of the investigated cores are based on the data provided by foraminifers (Sigal, this volume) and nannoplankton (Blechschmidt, this volume). Palynomorphs of potential chronostratigraphic value are discussed in the Site Report (this volume).

The carbonaceous interval is represented by Cores 56 to 138 . This interval is 795 meters thick, extending from 945 meters sub-bottom (Core 56) to the bottom of the hole at 1740 meters (Core 138). Arthur (this volume) has interpreted the origin of the carbonaceous interval. Two lithostratigraphic units were distinguished within this interval. The upper unit is composed of dark laminated and bioturbated mudstones and claystones grading downward into dark organic shales with thin dolomitic layers. Thin turbiditic sandstones, siltstones, and calcareous debris flow layers with mudchip conglomerates occur in the lower part. The unit is 723 meters thick and ranges in age from Cenomanian to Barremian. The lower unit is composed of bluish white nannoplankton limestones interbedded with varved brown mudstones. The lower unit is of late Hauterivian age and is 72 meters thick.

\section{MATERIALS AND METHODS}

Ninety-four samples from 69 of the cores representing the carbonaceous interval were studied (Table 1). Samples composed of fine-grained, dark-colored detrital material were selected wherever possible, although some limestone samples were also included, especially from the lowest part of the section. Because of major changes in the composition and size of the residues recovered after laboratory maceration, it was decided to count all palynomorphs mounted on the microscope slides, and to determine the character and estimate the abundance of the other carbonaceous particles.

Each sample was macerated by digesting the mineral sediment first in hydrochloric acid and then in hydrofluoric acid. The recovered residue was then treated with nitric acid to partially oxidize the organic matter, and with potassium hydroxide solution to remove humic acids. The resulting residues consisted of various proportions of dispersed land plant spores and pollen grains (sporomorphs) including spores larger than 200 microns in diameter, fungal spores and hyphae, small cellular algal(?) bodies, dinoflagellate cysts and small acritarchs (marine organic-walled phytoplankton), vascular plant cuticle, gymnospermous tracheal elements ("wood"), and particles without consistent external form. The relative abundance and occurrence of these materials fluctuates greatly in the section. For example, the number of palynomorphs on a microscope slide ranged form zero or a few to 1413 from samples in different parts of the section, and the number of palynomorph species from zero or one to 54 .

Fifty-two of the 94 samples were macerated so that the number of palynomorphs per sample of dried sediment could be calculated (Table 1). Each sample was dried, then weighed, prior to maceration. The weight of the samples varied from 0.88 to 1.55 grams. Then, the sample was macerated, and the residue was mounted in glycerine and weighed. A proportion was mounted on a microscope slide and its weight was determined. The ratio in weight of residue recovered to that mounted on the slide ranged from 56 to 80 times. The number of palynomorphs per gram of sediment was then calculated by multiplying the ratio of palynomorphs on a slide to the weight of the original sediment by the ratio of the weight of the macerated residue in glycerine to that of the proportion mounted on the slides, after the method described by Traverse and Ginsburg (1966).

The abundance of palynomorphs on a slide was compared with other parameters, such as the character of the other carbonaceous matter (structured palynodebris, amorphous palynodebris), the organic carbon percentages determined on board Glomar Challenger from other samples in the same cores, and the proportion of phytoplankton to sporomorphs. The calculated abundance of palynomorphs in the sediments was found to be generally consistent with the number of palynomorphs actually counted, and emphasizes the magnitude 
TABLE 1

List of Hole 398D Samples Studied

\begin{tabular}{|c|c|}
\hline $\begin{array}{c}\text { Sample } \\
\text { (Interval in } \mathrm{cm} \text { ) }\end{array}$ & $\begin{array}{c}\text { Calculated } \\
\text { No Specimen/g Dried Sediment }\end{array}$ \\
\hline $56-2,25-27$ & 1527 \\
\hline $56-2,132-138$ & - \\
\hline $56-3,16-18$ & - \\
\hline $56-3,89-91$ & - \\
\hline $56-4,19-21$ & - \\
\hline $57-1,117-119$ & - \\
\hline $57-2,25-27$ & 0 \\
\hline $57-4,69-71$ & - \\
\hline $\begin{array}{l}58-2,65-71 \\
58-2,72-74\end{array}$ & - \\
\hline $59-1,96-98$ & 654 \\
\hline $59-4,1-3$ & - \\
\hline $60-1,77-79$ & 1599 \\
\hline $60-1,148-150$ & - \\
\hline $61-2,1-3$ & 36 \\
\hline $62-1,34-36$ & - \\
\hline $62-5,60-62$ & - \\
\hline $62-5,90-92$ & 472 \\
\hline $\begin{array}{l}63-6,28-30 \\
65-2,20-22\end{array}$ & $\begin{array}{l}109 \\
181\end{array}$ \\
\hline $66-2,74-76$ & 363 \\
\hline $67-1,21-23$ & 545 \\
\hline $68-5,47-49$ & 1090 \\
\hline $69-3,108-110$ & 24,900 \\
\hline $71-4,87-89$ & - \\
\hline $73-2,107-109$ & 1024 \\
\hline $73-6,67-71$ & - \\
\hline $74-3,120-122$ & 6763 \\
\hline $76-1,42-44$ & 145 \\
\hline $76-1,142-144$ & - \\
\hline $76-3,92-94$ & - \\
\hline $77-2,10-12$ & 3231 \\
\hline $77, \mathrm{CC}$ & - \\
\hline $79-4,35-37$ & 7890 \\
\hline $81-4,6-8$ & - \\
\hline $82-2,49-51$ & 11,374 \\
\hline $93, \mathrm{CC}$ & - \\
\hline $84-5,55-57$ & 3074 \\
\hline $\begin{array}{l}84, \mathrm{CC} \\
85-1,48-50\end{array}$ & $5 \overline{840}$ \\
\hline $85-5,121-123$ & - \\
\hline $86-5,146-150$ & - \\
\hline $87-3,128-130$ & 2254 \\
\hline $88-6,91-93$ & 11,067 \\
\hline $88, \mathrm{CC}$ & - \\
\hline $90-3,35-37$ & - \\
\hline $90, \mathrm{CC}$ & - \\
\hline $91-3,120-122$ & 27,929 \\
\hline $92-7,4-6$ & $\overline{716}$ \\
\hline $93-6,89-91$ & 46,716 \\
\hline $93, \mathrm{CC}$ & - \\
\hline $94-2,21-22$ & 21,792 \\
\hline $95-6,129-131$ & 9643 \\
\hline $96-2,106-107$ & 58,990 \\
\hline $97, \mathrm{CC}$ & 17,702 \\
\hline $98-2,52-54$ & - \\
\hline $99, \mathrm{CC}$ & - \\
\hline $100-6,15-17$ & 17,784 \\
\hline $101-6,148-150$ & - \\
\hline $102-3,26-28$ & 19,037 \\
\hline
\end{tabular}

TABLE 1 - Continued

Calculated

(Interval in $\mathrm{cm}$ ) No.Specimen/g Dried Sediment

\begin{tabular}{|c|c|}
\hline $\begin{array}{l}102, \mathrm{CC} \\
103, \mathrm{CC} \\
104, \mathrm{CC} \\
105-3,97-99 \\
106-6,19-21\end{array}$ & $\begin{array}{l}- \\
- \\
\overline{-} \\
2510\end{array}$ \\
\hline $\begin{array}{l}107-3,51-53 \\
108-5,123-125 \\
111-2,140-142 \\
111, C C \\
112-1,108-110\end{array}$ & $\begin{array}{r}819 \\
1332 \\
1024 \\
- \\
5009\end{array}$ \\
\hline $\begin{array}{l}112, \mathrm{CC} \\
113, \mathrm{CC} \\
115-1,30-32 \\
115, \mathrm{CC} \\
118-7,40-45\end{array}$ & $\begin{array}{l}- \\
- \\
125 \\
-\end{array}$ \\
\hline $\begin{array}{l}119, \mathrm{CC} \\
120, \mathrm{CC} \\
121, \mathrm{CC} \\
122-7,10-12 \\
123-5,72-74\end{array}$ & $\begin{array}{r}12,649 \\
52,039 \\
- \\
71,013 \\
29,808\end{array}$ \\
\hline $\begin{array}{l}124-4,24-26 \\
125, \mathrm{CC} \\
126-1,71-73 \\
126-2,59-61 \\
127, \mathrm{CC}\end{array}$ & $\begin{array}{r}0 \\
-\quad 0 \\
- \\
-\end{array}$ \\
\hline $\begin{array}{l}129-7,38-41 \\
130-5,1-5 \\
132-2,148-150 \\
133, \mathrm{CC} \\
134-2,127-129\end{array}$ & $\begin{array}{r}88,485 \\
- \\
37,823 \\
0 \\
153\end{array}$ \\
\hline $\begin{array}{l}135-2,112-114 \\
136-2,136-138 \\
137-1,65-67 \\
138-2,90-92\end{array}$ & $\begin{array}{r}3586 \\
11,579 \\
34,943 \\
28,054\end{array}$ \\
\hline
\end{tabular}

with which the abundance of palynomorphs varies in the investigated section.

\section{CRETACEOUS PALYNOFACIES AT SITE 398}

The palynofacies of the carbonaceous interval was examined from the perspective of the sedimentology of palynomorphs and palynodebris recovered in the macerated residues (Combaz, 1964). The concept of palynodebris, as formulated by Manum (1976, p. 899), was modified to include amorphous carbonaceous particles. Carbonaceous particles which can be identified morphologically, e.g., the plant cuticle and pitted tracheids of vascular plants, are named structured palynodebris (cf. Manum, 1976), and those particles without consistent form but with distinctive optical properties are called amorphous palynodebris. The structured and amorphous palynodebris at Site 398 , as well as the palynomorphs, are considered to be the products of marine sedimentary processes (cf. Manum, 1976).

Three palynofacies are distinguished, based on the type of palynodebris and the general character of the palynomorph assemblages. These are exinitic, micrinitic, and xenomorphic. 
The exinitic palynofacies is characterized by large numbers of sporomorph exines, sporomorph species, and the abundance of structured palynodebris (Plate 1, Figure 1), to the almost total exclusion in the palynomorph assemblages of marine organic-walled phytoplankton. The sporomorph assemblages are diverse, and are characterized by the occurrence of striate schizaeaceous spores /Cicatricosisporites, Appendicisporites), and other larger and more highly ornamented species of pteridophyte spore genera, such as Trilobosporites, Pilosisporites, Foveotriletes, Sestrosporites, Microreticulatisporites, Densoisporites, Concavissimisporites, Murospora, Converrucosisporites, Dictyophyllidites, and Klukisporites. Classopollis torosus (Reissinger) occurs in high relative percentages throughout the Lower Cretaceous in Hole 398D, whether sporomorphs are abundant or rare in the samples. The sporomorph assemblages are similar to those described from coeval terrestrial sporomorph assemblages (cf. Brenner, 1963; Wolfe and Pakiser, 1971) and dissimilar to those described from the coeval western North Atlantic, e.g. DSDP Sites 99, 101, 105, 387, and 391 (described by Habib, 1977). The structured palynodebris is equally diverse and abundant, and is represented by larger $(>100 \mu \mathrm{m})$ specimens as well. Pitted tracheal elements and cellular plant cuticle comprise most of this palynodebris, which also include fungal spores and hyphae, and cellular algal (?) masses (Plate 1, Figures 5 and 6). Amorphous palynodebris is rare or absent in the exinitic palynofacies.

Both the palynomorphs and structured palynodebris usually are preserved very well. They are mostly optically translucent, pale yellow to yellow-brown, and show red safranin stain well. However, tracheal elements may also be dark brown and semi-opaque.

The micrinitic palynofacies (Plate 1, Figure 3) is characterized by an overwhelming abundance of amorphous palynodebris in the form of small $(>20 \mu \mathrm{m})$ even-sized, nearly equidimensional carbonaceous particles which appear to lack visible internal morphology. The particles are optically mostly opaque or semiopaque, and black to dark brown. They do not show stain in red safranin solution. Structured palynodebris may occur, but it is rare and appears carbonized.

In contrast to the exinitic palynofacies, the number of palynomorphs is usually much smaller, and the proportion of phytoplankton to sporomorphs is high. The small numbers of sporomorphs are represented by high percentages of Classopollis torosus and species of bisaccate pollen genera (Alisporites, Pinuspollenites) as well as consistently lower percentages of other cosmopolitan species in the Lower Cretaceous, such as Exesipollenites tumulus Balme, Eucommiidites minor Groot and Penny, Ginkgocycadophytus nitidus (Balme), Taxodiacaepollenites hiatus (Potonié), Cyathidites minor Couper, C. australia Couper, and Gleicheniidites senonicus Ross sensu Skarby, among others. These taxa occur in all three palynofacies. The phytoplankton occur in a larger number of species in a sample. Each species, however, is represented by a small number of specimens.

The xenomorphic palynofacies is characterized by the abundance of amorphous palynodebris with irregular outline and shredded appearance (Plate 1, Figure 4). Evidence of visible internal structure is lacking and the particles range in size from very small $(>15 \mu \mathrm{m})$ to relatively large (50-100 $\mu \mathrm{m})$. Xenomorphic palynodebris differs form other amorphous palynodebris by its optical translucence, its pale yellow or orange color, and it stains in safranin solution, suggesting a comparatively high volatile organic composition.

The number of palynomorphs in a sample is variable in the xenomorphic palynofacies and usually is small. Like the micrinitic palynofacies, the palynomorph assemblages in the Lower Cretaceous are characterized by high percentages of phytoplankton and a sporomorph flora dominated by Classopollis torosus and species of bisaccate pollen. In those samples where there is a large number of palynomorphs, sporomorphs may be more frequent than phytoplankton, although the sporomorph flora is still dominated by Classopollis and bisaccate pollen grains.

\section{PALYNOSTRATIGRAPHIC INTERVALS}

Seven palynostratigraphic units are distinguished, based primarily on the sequence of palynofacies. Figure 2 shows the palynostratigraphic units and corresponding palynofacies, as well as the number of palynomorphs per microslide, number of sporomorphs per microslide, proportion of phytoplankton to sporomorphs (percentage phytoplankton), and percentage of organic carbon. The biostratigraphic ages of the units are shown for comparison.

Palynostratigraphic Units I and VII are distinguished on the basis of their contained xenomorphic palynofacies. The xenomorphic facies also occurs in samples from two cores in palynostratigraphic Unit II, which is otherwise characterized by the exinitic palynofacies. The exinitic and micrinitic palynofacies form repetitive sequences throughout the major part of the section, in Barremian-Aptian (Units II and III) and Albian sediments (Units IV and V-VI), which suggests a casual relationship. Units V and VI are both characterized by a micrinitic facies, but are distinguished by the abundance of palynomorphs and the kind of palynomorph assemblage.

Palynostratigraphic Unit I (Cores 138 to 133) is characterized by an abundance of xenomorphic palynodebris and a fluctuation in the number of palynomorphs. The lower part of the unit (Cores 138 to 135) contains a flora composed mostly of Classopollis torosus, and Pinuspollenites spp., as well as minor amounts of the cosmopolitan gymnosperm pollen and pteridophyte spores. Classopollis and Pinuspollenites vary between 67 and 74 per cent of the palynomorph assemblages. Dinoflagellate species are common, but each is represented by only a few specimens. Striate schizaeaceous spores are rare, occurring at less than 2 

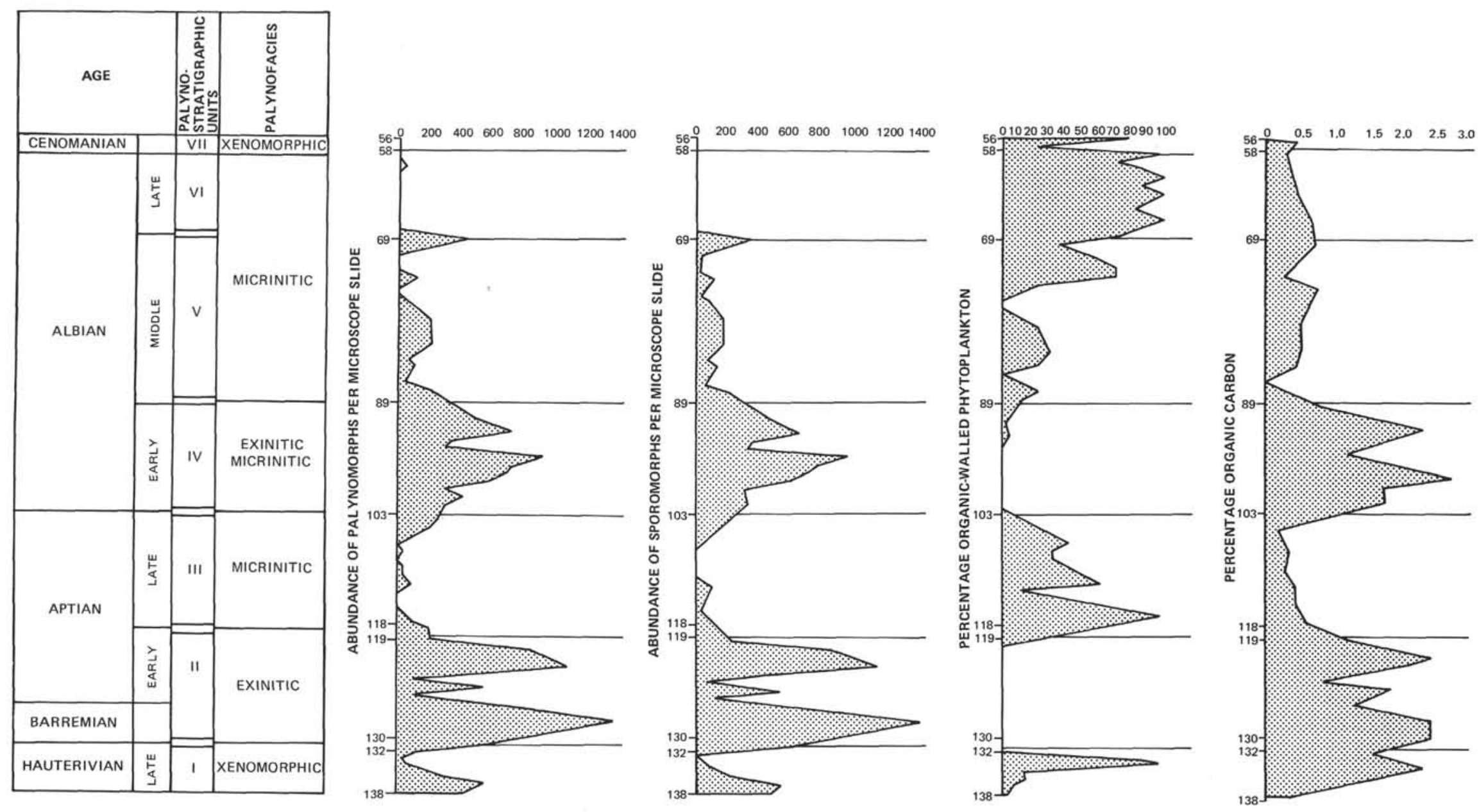

Figure 2. Palynomorph abundance profiles compared with organic carbon percentage profile. 
per cent in the samples. The upper part of Unit I (Cores 134 and 133) contains very few palynomorphs, which are represented entirely by small acritarchs. Palynomorph specimens/gram range from 3,586 to 34,943 in the lower part, and from 0 to 153 in the upper. An average of 13,052 specimens/gram was calculated for the entire interval. Organic carbon percentages are relatively high. The unit is approximately 63 meters thick and has been dated late Hauterivian.

Palynostratigraphic Unit II (Cores 132 to 119) is characterized by the exinitic palynofacies. With the exception of Samples 398D-126-2, 59-61 cm; 398D-126-1, 71-73 cm; and 398D-124-4, 24-26 cm, which contain abundant xenomorphic palynodebris and are barren of palynomorphs, this interval is represented by the greatest abundance of structured palynodebris, sporomorphs, and sporomorph species in the section. The palynodebris is the most varied, containing vascular plant tracheal elements and cellular cuticle, algal(?) cellular masses, fungal spores and hyphae, and spores $200 \mu \mathrm{m}$ in diameter. The sporomorph assemblages are also the most varied in the section. Except for Core 119 which contains 39 species of sporomorphs, the species in this interval range from 44 to 54 per sample. In addition to the high percentages (ca. 40\%) of Classopollisbisaccates, the sporomorph assemblages of palynostratigraphic Unit II contain many species and specimens of striate spores and other larger and highly ornamented spores. For example, in sample 398D$123-5,72-74 \mathrm{~cm}$, Classopollis-biaccates comprise 32 per cent of the assemblage, whereas striate spores comprise 34 per cent in 12 species. The number of striate spore species ranges from 11 to 15 per sample, and averages 12.6 per sample. The remainder of the assemblage consists of larger pteridophyte spores (e.g., Trilobosporites, Converrucosisporites, Densoisporites), and the ubiquitously distributed smaller spores (e.g., Cyathidites, Gleicheniidites) and pollen grains (e.g., Eucommiidites, Vitreisporites). Organic-walled phytoplankton are virtually absent, with no specimens found in the assemblages from most samples. Sporomorphs are also the most numerous; the specimens per gram of dried sediment range from 12,649 in Sample 398D-119, CC to 88,485 in $398 \mathrm{D}-129-7,38-41 \mathrm{~cm}$, and average 48,636 per gram for the interval.

The abundance of sporomorphs and structured palynodebris coincides with relatively high organic carbon percentages (Figure 2). Palynostratigraphic Unit II is approximately 124 meters thick and is dated as Barremian-early Aptian.

Palynostratigraphic Unit III (Cores 118 to 104) contains the micrinitic palynofacies. Micrinitic palynodebris is abundant. However, in samples from Cores 115 and 111, there is an admixture of micrinitic and small xenomorphic palynodebris. Palynomorphs are much fewer than in Unit II, ranging from 125 specimens/gram in Core 115 to 5009 in Core 112. The average abundance is 1803 per gram. Although few palynomorph specimens occur on a microscope slide, between 30 and 100 per cent consist of organic-walled phytoplankton in most samples. An exception occurs in Sample 398D-112-1, 108 to $110 \mathrm{~cm}$, where Classopollis and bisaccate species of Pinuspollenites and Alisporites comprise more than 57 per cent of the total palynomorph assemblage and where three species of dinoflagellates comprise 10 per cent. The number of palynomorph species is also few, ranging from one species of acritarchs in Core 115 to 15 species of palynomorphs (of which 12 are sporomorph) in Core 112. Sporomorph species are usually slightly more frequent that phytoplankton species. Striate spores are very rare in this interval, and are represented by smaller specimens.

The organic carbon percentages in sediments of palynostratigraphic Unit III are low, which coincides with the small number of palynomorphs of which a high percentage is phytoplankton. The unit is approximately 142 meters thick, and is dated as late Aptian.

Palynostratigraphic Unit IV (Cores 103 to 90) marks the recurrence of the exinitic palynofacies, within which there is a stratigraphic interval (represented by Cores 94 to 92) containing the micrinitic facies. Palynomorphs are abundant throughout Unit IV, ranging from 9643 to 58,990 specimens per gram, and averaging 27,449 per gram. Sporomorphs are most abundant in this facies, to the almost total exclusion of marine phytoplankton. The sporomorph assemblages are characterized by striate spores, but to a lesser extent than in Unit II (Figure 3). For example, the number of striate species averages 7, while it averages 12.6 in Unit II. The number of species in samples of the exinitic facies ranges from 25 to 34 , although only 17 were distinguished in sample 398D-95-6, 129-131 cm.

The palynomorph assemblages of the micrinitic interval in palynostratigraphic Unit IV are also dominated by sporomorphs. Phytoplankton comprises only up to 4 per cent of the assemblage, in Sample 398D-93-6, 89 to
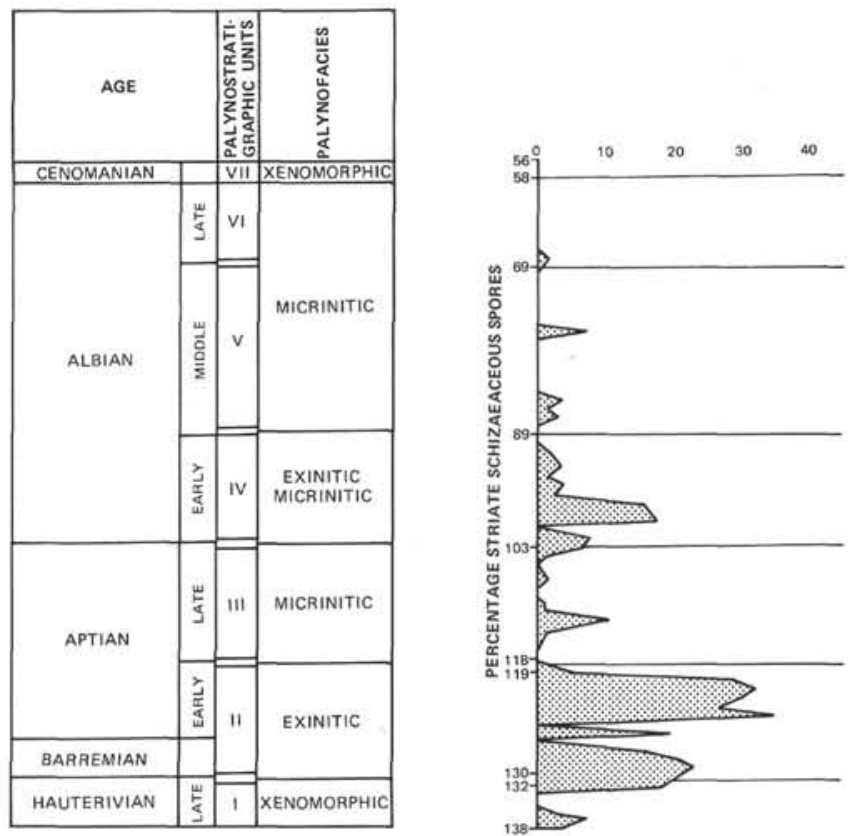

Figure 3. Percentage of striate schizaeaceous spores. 
$91 \mathrm{~cm}$. In contrast to the exinitic facies, the sporomorphs are dominated by Classopollis and bisaccates, which together comprise between 64 and 77 per cent of all palynomorphs; striate spores are few.

Palynostratigraphic Unit IV is similar to Unit II, in that both contain an exinitic palynofacies characterized by abundant sporomorphs, sporomorph species, and structured palynodebris. Unit IV differs from Unit II in the degree to which the facies is expressed. For example, there are slightly fewer specimens and species in Unit IV. Also, the palynodebris is equally abundant although not as diverse, in that is is composed predominantly of tracheal elements. Comparison of the organic carbon composition for the two units shows equally high percentages (Figure 2). The unit is approximately 124 meters thick, and has been dated as early Albian.

Palynostratigraphic Unit V (Cores 88 to 69) contains the micrinitic palynofacies. Characterized by the abundance of micrinitic palynodebris, it contains few palynomorphs and higher percentages of phytoplankton. In most samples, palynomorphs vary from 145 to 11,374 specimens/gram, and palynomorph species vary from 2 to 24. However, a notable exception occurs in the sample from Core 69 , in which 24,900 specimens/gram were calculated and 27 palynomorph species were observed. The average abundance for all samples is 7050 per gram. The assemblages are characterized by high percentages of sporomorphs of Classopollis and bisaccates, and by phytoplankton. Phytoplankton percentages show a generalized increase stratigraphically upward through this interval. Organic carbon percentages remain relatively low. Unit V is approximately 218 meters thick and has been dated as middle Albian. It is otherwise distinguished from the previously described units by the occurrence of tricolpate angiosperm pollen throughout, although they remain subordinate in percentage to Classopollis torosus and species of Pinuspollenites and Alisporites. Although the palynomorph assemblages are meager, the dinoflagellate flora appears to become more diverse toward the top of the unit, where species of Deflandrea become important elements.

Palynostratigraphic Unit VI (Cores 68 to 58) also contains abundant micrinitic palynodebris, but is distinguished by even fewer palynomorphs. In all the samples from this interval, only 36 to 1599 specimens/ gram were calculated, and the number of palynomorph species in a sample varies from 1 to 12 . The average abundance was calculated to be 505 specimens per gram. Of the few palynomorphs, between 68 and 100 per cent are phytoplankton. Organic carbon percentages are relatively low, similar to that of palynostratigraphic Units III and V. Palynostratigraphic Unit VI is approximately 105 meters thick and has been dated as late Albian, including Vraconian.

Palynostratigraphic Unit VII (Cores 57 to Section 56-2) is distinguished by a rich xenomorphic palynofacies and few palynomorphs. In most of the samples, xenomorphic palynodebris is extremely abundant in the residues, and few or no palynomorphs were recovered. In Sample 398D-56-2, 25-27 cm, 42 specimens were counted, which calculates to 1527 specimens/ gram. The assemblage consists of dinoflagellate species of Deflandrea and Subtilisphaera, small acritarchs, and two species of Normapolles pollen genera, including $\mathrm{cf}$. Atlantopollis sp.

The organic carbon percentages are relatively low for Unit VII, although the highest value for the entire section was recorded in a sample from Core 56. The unit is approximately 16 meters thick and has been dated as Cenomanian.

\section{SUMMARY AND CONCLUSIONS}

The carbonaceous section of Cores 138 to 56 in Hole 398D is interpreted on the basis of the sedimentation of sporomorphs and organic-walled phytoplankton, according to their distribution in the exinitic, micrinitic, and xenomorphic palynofacies. The exinitic facies has higher percentages of organic carbon, and it is concluded that the influx of abundant terrestrial vegetal debris composed mainly of sporomorphs, tracheids, and cuticular matter was responsible for its increased carbonaceous composition. Evidence for this conclusion is drawn from the fact that the macerated residues are composed almost entirely of the materials of land plants. The assemblages show a closer compositional relationship to coeval terrestrial assemblages than to contemporaneous marine assemblages at DSDP sites drilled in the western North Atlantic. Additional evidence for a terrestrial source is taken from the abundance of the sporomorphs in this palynofacies. This abundance compares with studies of modern sediments showing the concentration of sporomorphs in marine sediments opposite discharge areas of deltas. For example, Cross et al. (1966) showed that in the Gulf of California, major concentrations of sporomorphs, cuticles, and tracheids occur at delta mouths and in some deep submarine channels, as well as in silty clays slightly offshore. Muller (1959) showed similar results for the Orinoco drainage system, where sporomorphs were concentrated in marine sediments near areas of deltaic sedimentation. These authors stress the importance of marine currents in redistributing selected morphotypes away from the areas of major terrigenous influx.

The occurrence of numerous striate schizaeaceous spores in the Lower Cretaceous exinitic facies is considered to be significant, because of its rarity in the western North Atlantic and in the other palynofacies at Site 398, and its regular occurrence throughout Lower Cretaceous terrestrial assemblages. Brenner (1963) reported the predominance of striate spores (and Classopollis torosus) among other trilete pteridophyte spores in terrestrial sediments of the Lower Cretaceous Potomac Group of Maryland. Wolfe and Pakiser (1971) stressed the stratigraphic utility of these spores in their study of the Potomac Group, stating that as many as 75 species of striate spores were distinguished, which they correlated with the diverse megascopic flora of the Family Schizaeaceae in the sediments. They reported an 
average of 12 species per assemblage in the upper (Albian) part of the Potomac Group, which compares favorably with the number of striate species occurring in palynostratigraphic Units II and IV. Similar results were obtained in the Lower Cretaceous of the Scotian Shelf and Grand Banks off eastern Canada. Williams (1975) described Neocomian assemblages from the lower part of the fluvio-deltaic Missisauga Formation which are dominated by schizaeaceous spores. Williams and Brideaux (1975) dated a late Albian palynoflora in which trilete spores were abundant, including numerous species of Cicatricosisporites and Appendicisporites. They interpreted these data to indicate that the location of their core holes was very close to the Albian shoreline and possibly in a nonmarine locale. In her study of marine Aptian and Albian assemblages from southern England, Kemp (1970) compared their palynology with the underlying, largely nonmarine, upper Wealden facies, and noted that the abundance and diversity of fern spores, particularly those attributable to the Family Schizaeaceae decreases upwards with a concomitant increase in the abundance of bisaccate pollen grains.

Because of the distribution of striate spores in nonmarine assemblages throughout the Lower Cretaceous, it is concluded that their more numerous occurrence in the exinitic facies of Site 398 is a measure of the higher rate of sedimentation of terrigenous organic matter (Figure 3).

In contrast to the exinitic palynofacies, the micrinitic facies is considered to represent the much diminished terrigenous sedimentation of plant materials. This is based on the smaller numbers of sporomorphs, the apparently sorted sporomorph flora composed mostly of Classopollis and bisaccates, the higher proportion of phytoplankton, and the prominence of small micrinitic palynodebris. These assemblages reflect the influence of marine currents, which may have sorted out the larger and more ornamented pteridophyte spores, including striate spores, and concentrated those sporomorphs which were morphologically adapted for transportation in currents. The morphotypes represented by Pinuspollenites-Alisporites and Classopollis, correspond well to this interpretation. Traverse and Ginsburg (1966) have demonstrated that bisaccate pollen of modern pine are buoyant in water and remains suspended for relatively long periods of time. In their study of the palynology of surface sediments of the Great Bahama Bank, which are essentially devoid of terrigenous sediment, they showed that the distribution of these bisaccate pollen corresponded to marine sedimentation patterns, and not source vegetation. Pinuspollenites and Alisporites may have responded in the same manner, as they possess the same basic morphology and are presumed to have been dispersed from anemophilous conifers. Classopollis torosus is a small (ca. $30 \mu \mathrm{m}$ ), spheroidal pollen species with diminutive ornamentation, which was dispersed from an extinct group of conifers (Brenner, 1963). Its smaller size and shape suggest that this species was more easily transported by marine currents. C. torosus has a ubiquitous distribution in the Lower Cretaceous in Hole 398D. Figure 4 shows that it is abundant in the ex-
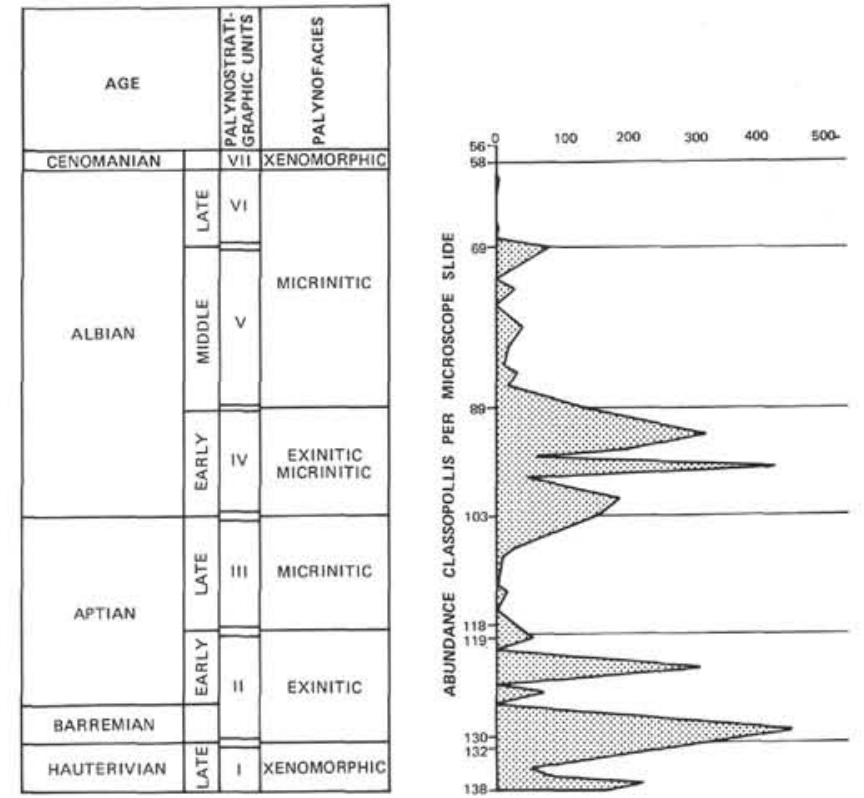

Figure 4. Classopollis abundance profile.

initic facies, and occurs in high percentages there as well as in the palynofacies characterized by fewer sporomorphs. This suggests that the species was transported equally with the other sporomorphs of the exinitic facies, and not at the expense of their sedimentation. This would not be expected if the exinitic facies represented a change of source vegetation. Rather, it most likely reflects the transportability of Classopollis in marine currents, as this pollen genus is well represented in the relative frequencies of both richly and poorly palyniferous assemblages.

The association of bisaccates, Classopollis, and phytoplankton in the micrinitic facies can be compared with the study of Cross et al. (1966). They indicated that for the Gulf of California, pine and mangrove pollen increase in relative frequency away from the direct influence of deltaic sedimentation, and that dinoflagellate cysts increase in absolute frequency. Mangrove pollen are similar in gross morphology to Classopollis, in that both are small and essentially spheroidal, and thus may be similarly sedimented.

The abundant, small, even-sized, and apparently carbonized micrinitic palynodebris may also represent vegetal materials which have been selectively transported. transported.

The relatively low organic carbon percentages associated with the micrinitic palynofacies in Hole 398D reflect the much smaller contribution of vascular plant materials. The contribution of pelagic organic matter to the composition of these sediments is not clear, since marine phytoplankton do occur in high percentages in the assemblages. Also, there are samples in the micrinitic facies, e.g., 398D-69-3, 108-110 cm, which contain an abundance of sporomorphs, representing episodes of increased terrigenous debris.

The interpretation of the xenomorphic palynofacies differs from those given for the exinitic and micrinitic 
facies, as there apparently is no direct correlation between the abundance of palynomorphs and the amount of organic carbon in the sediments. For example, in palynostratigraphic Unit I, the abundance of palynomorphs varies markedly although the organic carbon percentages are consistently high. In Unit VII, palynomorphs are very few and the organic carbon percentages are relatively low. However, according to the Site Report (this volume), the highest organic carbon content was recorded from a sample of Cenomanian age in Core 56 (Unit VII). This lack of correspondence between the palynomorph content and the organic carbon composition in the xenomorphic palynofacies suggests that factors other than, or in addition to, the contribution of terrestrial plant material were responsible for the carbonaceous composition of the sediments. The carbonaceous components in Units I and VII may reflect a large admixture of pelagic carbon, represented perhaps in the abundance of xenomorphic palynodebris.

The character of the palynomorph assemblages is in accordance with this interpretation. In palynostratigraphic Unit I, the assemblages contain high percentages of Classopollis and bisaccate pollen, as well as small acritarchs and 15 species of dinoflagellates. In Unit VII, palynomorphs are very few, but phytoplankton in Sample $398 \mathrm{D}-56-2,25$ to $27 \mathrm{~cm}$ comprise more than 80 percent of the assemblage. Thus, the character of the assemblages is similar to that of the micrinitic facies, and the sporomorphs are considered to have been sedimented in response to selective sorting by marine currents rather than by high rates of terrigenous influx.

The palynological history for most of the late Hauterivian-Cenomanian can be interpreted in terms of the episodic sedimentation of terrestrial plant materials in response to increased, then diminished deltaic activity. Modern deltas are known to be major contributors of sporomorphs to the marine environment, and during the Early Cretaceous much of the margin of the North Atlantic was characterized by major deltaic systems. During the Barremian-early Aptian, and again during the early Albian, deltaic progradation provided abundant land plant sporomorphs, cuticles, and tracheids to the area south of Vigo Seamount, probably within prodeltaic distal turbidites (Site Report, this volume). The exinitic palynofacies which was emplaced during these intervals is considered to have been responsible for the increased carbonaceous composition of the representative sediments. In each succeeding time period (e.g., during the late Aptian and middle Albian), deltaic sedimentation was sharply diminished and marine currents deposited mostly those sporomorphs which were morphologically adapted for selective transportation, as well as abundant fine micrinitic palynodebris. The occurrence in high percentages of dinoflagellate cysts and small acritarchs during these episodes may reflect the removal of the masking effect of high sporomorph sedimentation combined with the increased productivity of organic-walled phytoplankton. The smaller amounts of spcromorphs in these sediments may account for their lesser carbonaceous composition, although the contribution of pelagic organic carbon is not known. In the late Albian, even fewer terrigenous palynomorphs were deposited in the micrinitic palynofacies, as the palynomorph assemblages formed at this time were made up almost entirely of dinoflagellate cysts. The reduction in number of sporomorphs sedimented between the middle and late Albian, despite the relatively constant (albeit low) organic carbon sedimented, suggests the increased role of pelagic organic carbon.

During the late Hauterivian and the Cenomanian, the xenomorphic palynofacies was deposited in a pelagic environment away from any influence of deltaic sedimentation. The high percentages of organic carbon in selected samples from palynostratigraphic Units I and VII may relfect the pelagic origin of xenomorphic palynodebris, although there is no direct palynological evidence from Hole 398D to indicate this.

In conclusion, the close correspondence between the sporomorph and total palynomorph abundance curves (Figure 2) shows that the Hauterivian-Cenomanian assemblages in Hole 398D are composed almost entirely of land plant sporomorphs, and that dinoflagellates and small acritarchs are frequent only in those samples containing few palynomorphs. The close correspondence between the sporomorph abundance and percentage organic carbon curves, at least in the Barremian-middle Albian interval, indicates that the carbonaceous composition of these sediments was derived from land plants. The exinitic palynofacies was formed during periods of increased sedimentation of terrigenous vegetal debris, such as within distal turbidites associated with deltaic progradation. The calculated average greater abundance of sporomorphs in palynostratigraphic Unit II than in Unit IV may indicate that deltaic sedimentation was more prominent in the area south of Vigo Seamount during the Barremian-early Aptian than during the early Albian. This conclusion is supported by the smaller number of striate spore species and the occurrence of micrinitic palynodebris in palynostratigraphic Unit IV. The micrinitic palynofacies was formed during periods of decreased deltaic activity, when marine currents were directly responsible for the deposition of selected sporomorph types.

The xenomorphic palynofacies was formed in a pelagic environment. Although there is no direct palynological evidence, the xenomorphic palynodebris nevertheless may be of marine origin. In the sub-surface Upper Cretaceous of New Jersey, the xenomorphic palynofacies occurs in intervals of marine transgression and the exinitic palynofacies, represented by numerous specimens and species of angiosperm pollen, is abundant in intervals of terrigenous sedimentation during marine regression (R. Aurisano, Rutgers University, personal communication).

Based on the pyrolysis of Aptian-Cenomanian organic matter of Hole 398D, Deroo et al. (this volume) have concluded that it is predominantly detrital and of 
continental origin. De Graciansky and Chenet (this volume) came to the same conclusion on the basis of their sedimentological study of the organic matter.

\section{ACKNOWLEDGMENTS}

Rochelle Susan Habib assisted in the collection of data. Barbara Ann Barreiro and Valerie Krass macerated the samples. Sheldon Nelson prepared the samples in which the weight abundances of palynomorphs were calculated.

The organic carbon data were collected by Anne Gilbert on board D/V Glomar Challenger.

This study was supported by a grant from the National Science Foundation NSF OCE 76-14619.

H.L. Cousminer reviewed the manuscript.

\section{REFERENCES}

Brenner, G.J., 1963. The spores and pollen of the Potomac Group of Maryland, Maryland, Dept. Geol. Mines Water Res., Bull. 27.

Combaz, A., 1964. Les palynofacies, Rev. Micropaleontol., v. 7, p. $205-218$.

Cross, A.T., Thompson, G.G., and Zaitzeff, J.B., 1966. Source and distribution of palynomorphs in bottom sediments, southern part of Gulf of California, Marine Geol., v. 4 , p. $467-524$.

Habib, D., 1977. Comparison of Lower and Middle Cretaceous palynostratigraphic zonations in the western North Atlantic. In Swain, F.M. (Ed.), Stratigraphic micropaleon- tology of Atlantic Basin and borderlands: Amsterdam (Elsevier Scientific Publishing Co.), p. 341-367.

Kemp, E.M., 1970. Aptian and Albian miospores from southern England, Paleontographica, v. 131, p. 73-143.

Manum, S.B., 1976. Dinocysts in Tertiary Norwegian-Greenland Sea sediments (Deep Sea Drilling Project Leg 38), with observations on palynomorphs and palynodebris in relation to environment. In Talwani, M., Udintsev, G., et al., Initial Reports of the Deep Sea Drilling Project, v. 38, Washington (U.S. Government Printing Office), p. 398-419.

Muller, J., 1959. Palynology of Recent Orinoco delta and shelf sediments: Reports of the Orinoco Shelf Expedition, Micropaleontology, v. 5, p. 1-32.

Traverse, A. and Ginsburg, R.N., 1966. Palynology of the surface sediments of Great Bahama Bank, as related to water movement and sedimentation, Marine Geol., v. 4, p. 417-459.

Williams, G.L., 1975. Dinoflagellate and spore stratigraphy of the Mesozoic-Cenozoic, offshore eastern Canada, Geol. Surv. Canada, Paper 74-30, v. 2, p. 107-161.

Williams, G.L. and Brideaux, W.W., 1975. Palynological analysis of late Mesozoic-Cenozoic rocks of the Grand Banks of Newfoundland, Geol. Surv. Canada, Bull. 236.

Wolfe, J.A. and Pakiser, H.M., 1971. Stratigraphic interpretations of some Cretaceous microfossil floras of the Middle Atlantic States, U.S. Geol. Surv. Prof. Paper 750-B, p. B35-B47. 



\section{PLATE 1}

Figures 1, 2, Exinitic palynofacies. 5-7

1. Specimen of Appendicisporites shown, as well as structured palynodebris in the form of tracheids with bordered pits, and a fungal spore. Sample 398D-123-5, $72-74 \mathrm{~cm}$.

2. Structured palynodebris. Vascular plant cuticle. Sample 398D-122-7, 10-12 cm.

5 , 6. Structured palynodebris. Multicellular bodies of probable algal origin. 5. Sample 398D$132-2,148-150 \mathrm{~cm}$. 6. Sample 398D-129-7, $38-41 \mathrm{~cm}$.

7. Appendicisporites erdtmanii Pocock. Sample 398D-97, CC.

Figure 3 Micrinitic palynofacies. Amorphous palynodebris composed mostly of small opaque or semiopaque, black particles. Sample 398D-62-5, 90-92 $\mathrm{cm}$.

Figure 4 Xenomorphic palynofacies. Amorphous palynodebris composed mostly of optically translucent yellow, brown and orange particles. Sample 398D-56-2, $25-27 \mathrm{~cm}$. 
PLATE 1
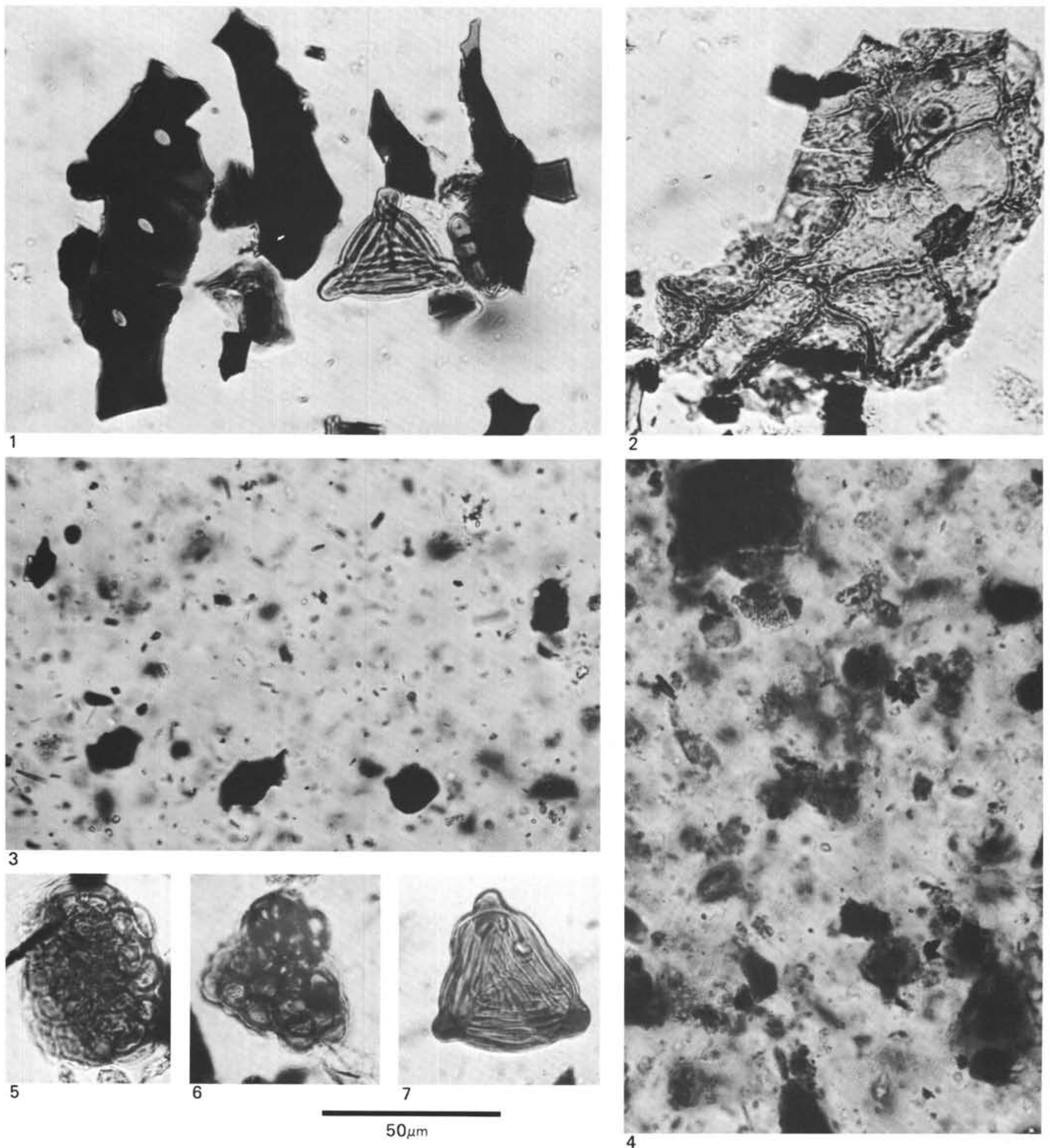


\section{PLATE 2}

Spores Typical of Exinitic Palynofacies

Figure 1 Trilobosporites crassus Brenner. Sample 398D-123-5, $72-74 \mathrm{~cm}$.

Figure 2 Trilobosporites marylandensis Brenner. Sample 398D-120, CC.

Figure 3 cf. Trilobosporites sp. Valvae are entire and smooth. Sample 398D-123-5, $72-74 \mathrm{~cm}$.

Figure 4 Densoisporites sp. Sample 398D-123-5, $72-74 \mathrm{~cm}$.

Figure 5 Densoisporites microrugulatus Brenner. Sample 398D-97, CC.

Figure $6 \quad$ Foveosporites sp. Sample 398D-132-2, 148-150 cm.

Figure 7 Concavissimisporites punctatus (Delcourt and Sprumont). Sample 398D-122-7, 10-12 cm.

Figure $8 \quad$ Concavissimisporites sp. cf. C. variverrucatus Couper. Small verrucae of equal size distributed evenly on exine. Sample 398D-132-2, 148-150 cm.

Figure 9 Densosporites sp. Sample 398D-132-2, 148-150 cm.

Figure 10 Striate spore species. Sample 398D-132-2, 148-150 cm.

Figure $11 \quad$ Appendicisporites tricornitatus Weyland and Greifeld. Sample 398D-97, CC.

Figure 12 Concavisporites sp. Sample 398D-122-7, 10-12 cm.

Figure 13 Cicatricosisporites sp. Sample 398D-132-2, 148-150 cm.

Figure 14 Cicatricosisporites venustus Deak. Sample 398D-123-5, $72-74 \mathrm{~cm}$.

Figure 15 Cicatricosisporites sp. Sample 398D-119, CC.

Figure 16 Costatoperforosporites sp. Sample 398D-97, CC.

Figure 17 Appendicisporites sp. $\mathrm{cf}$. A. concentricus Kemp. Sample 398D120 , CC.

Figure $18 \quad$ Costatoperforosporites sp. Specimen near lower left corner is Gleicheniidites lamontensis Habib. Sample 398D-120, CC. 
PLATE 2
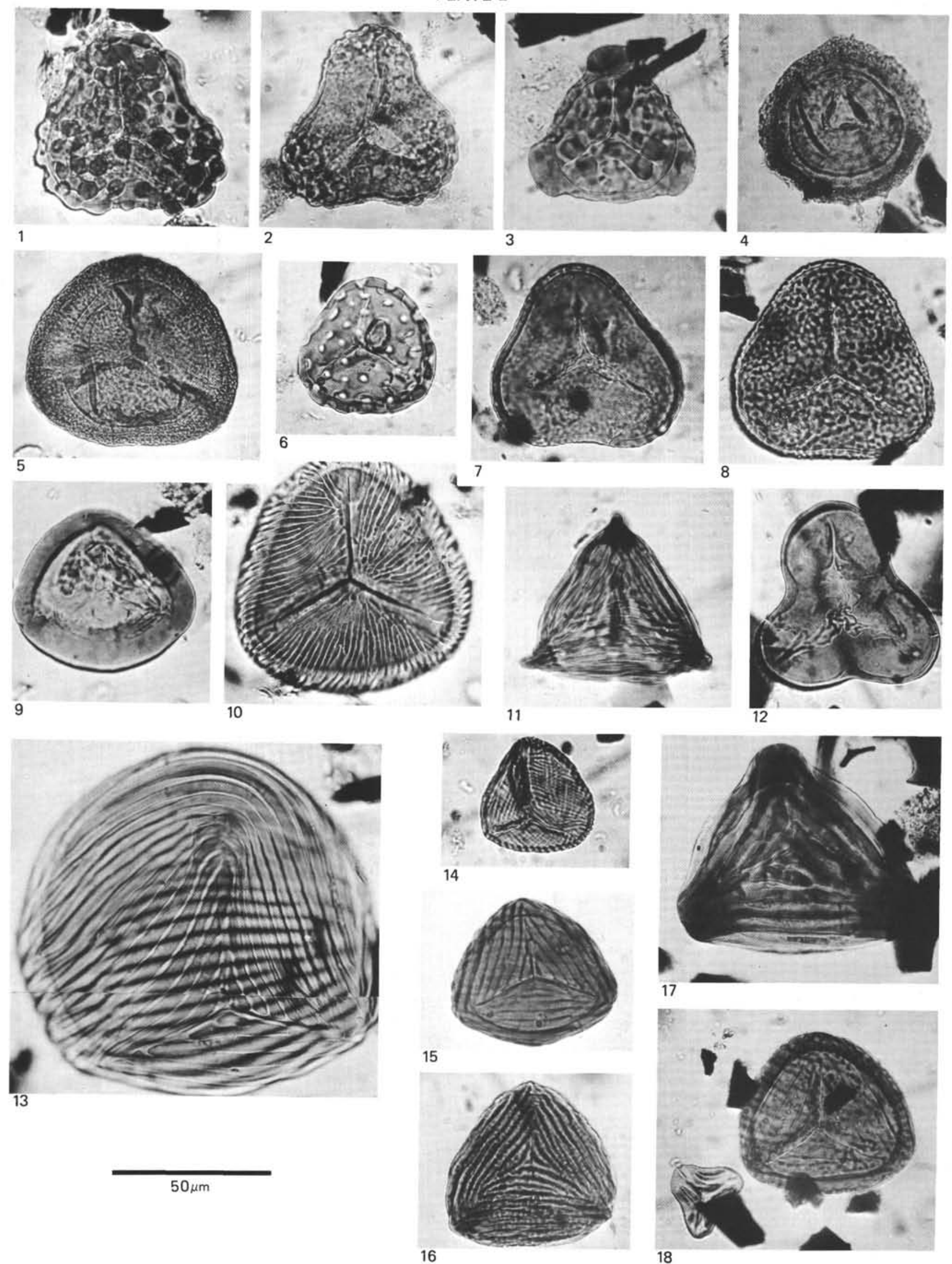


\section{PLATE 3}

Spores Typical of Exinitic Palynofacies

Figures 1, 2 Appendicisporites jansonii Pocock.

1. Sample 398D-122-7, 10-12 cm.

2. Sample 398D-119, CC.

Figure 3 Appendicisporites sp. Sample 398D-132-2, 148-150 cm.

Figure $4 \quad$ Costatoperforosporites sp. Sample 398D-122-7, 10-12 cm.

Figure $5 \quad$ Microreticulatisporites crassiexinous Brenner. Sample 398D-132-2, 148-150 cm.

Figure $6 \quad$ Converrucosisporites exquisitus Singh. Sample 398D-119, CC.

Figure $7 \quad$ Appendicisporites sp. cf. $A$. bifurcatus Singh. Sample 398D-132-2, 148-150 cm.

Figure 8 Appendicisporites sp. cf. Anemia macrorhyza (Maljavkina). Sample 398D-120, CC.

Figure 9 Cicatricosisporites hughesii Dettmann. Sample 398D-122-7, 10-12 cm.

Figure $10 \quad$ Cicatricosisporites $\mathrm{sp}$. Sample 398D-119, CC.

Figure $11 \quad$ Appendicisporites sp. Sample 398D-122-7, 10-12 cm.

Figure 12 Cicatricosisporites ludbrookii Dettmann. Sample 398D-122-7, 10-12 cm.

Figure 13 Appendicisporites cristatus (Markova). Sample 398D-122-7, 10-12 cm.

Figure $14 \quad$ Appendicisporites sp. Sample 398D-122-7, 10-12 cm. 
PLATE 3
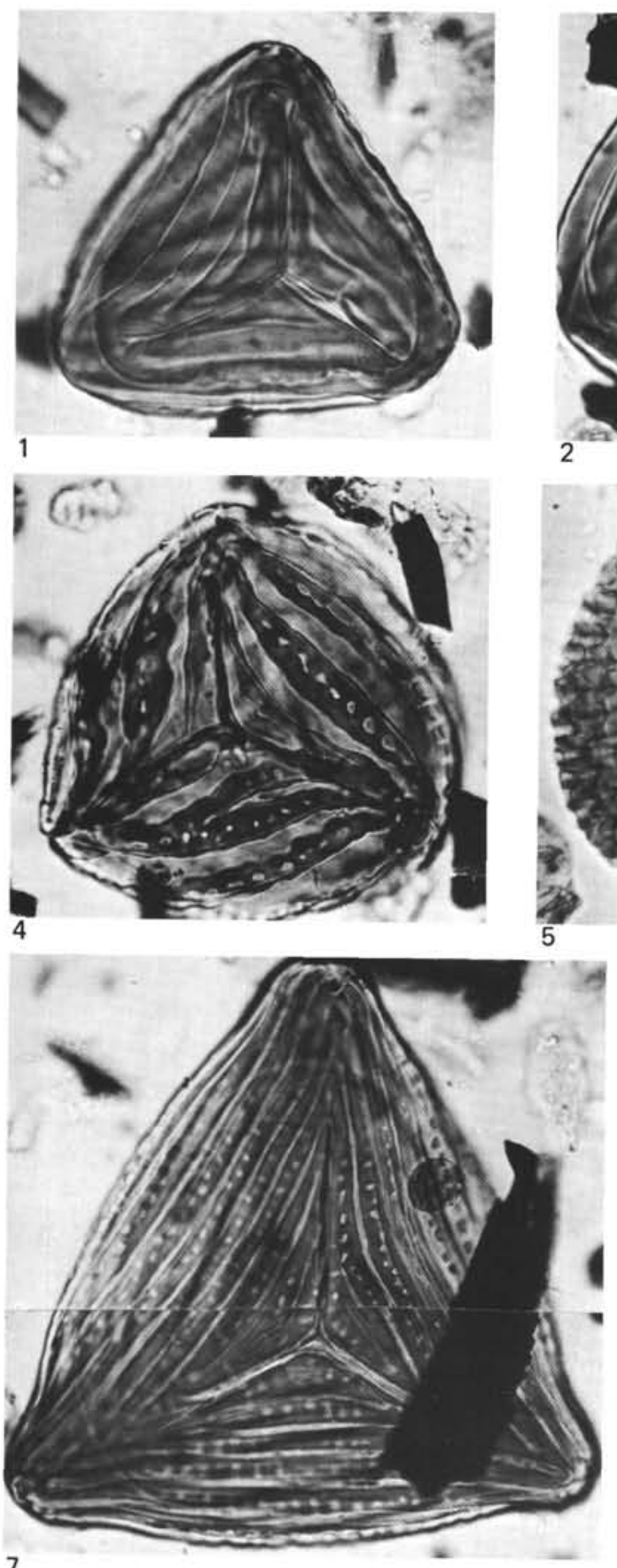

7
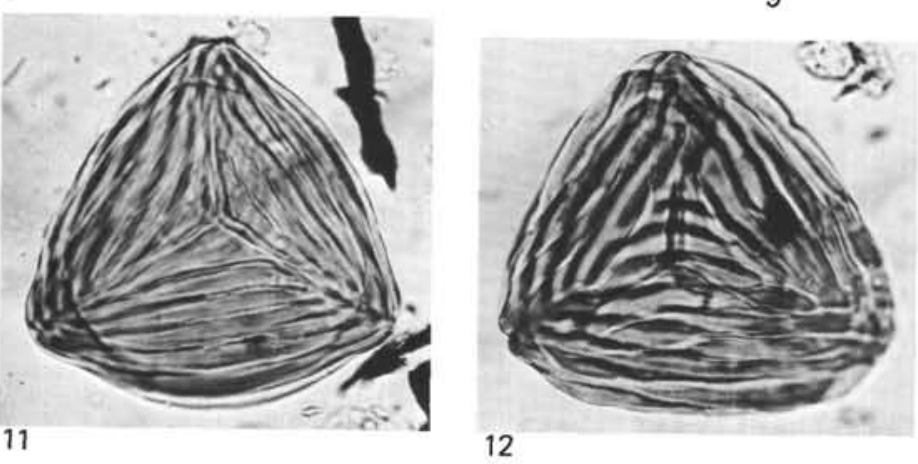
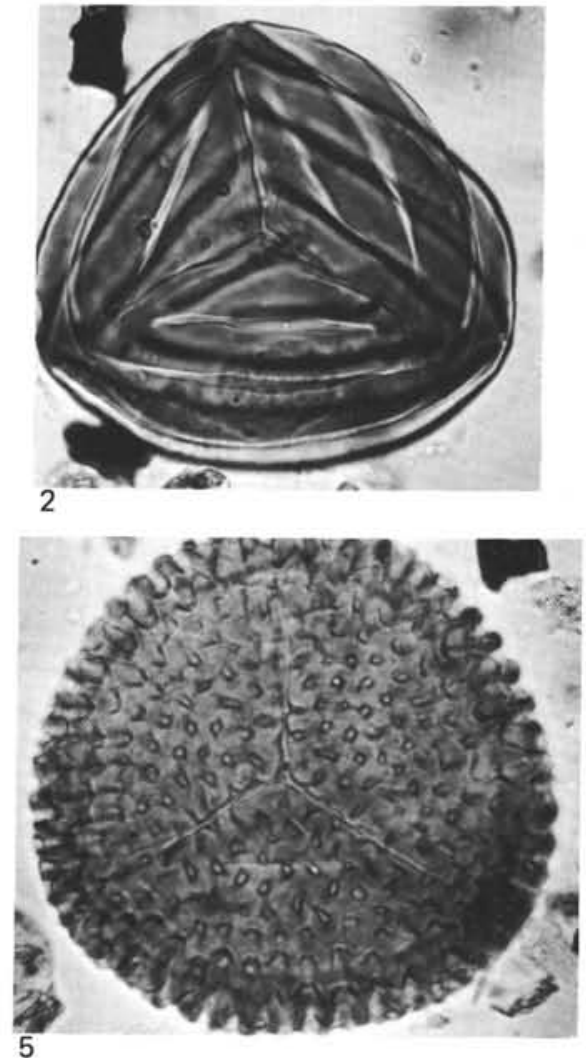

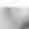

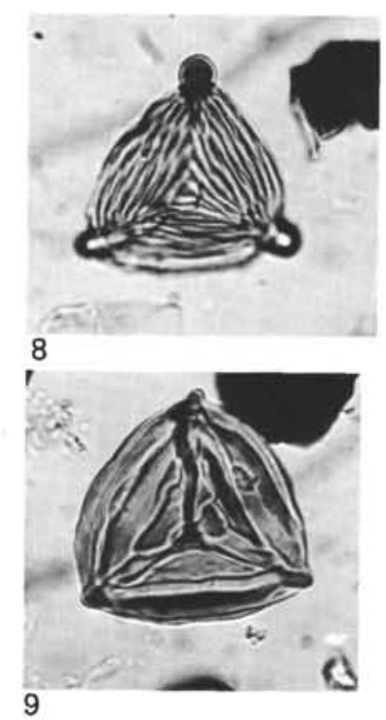

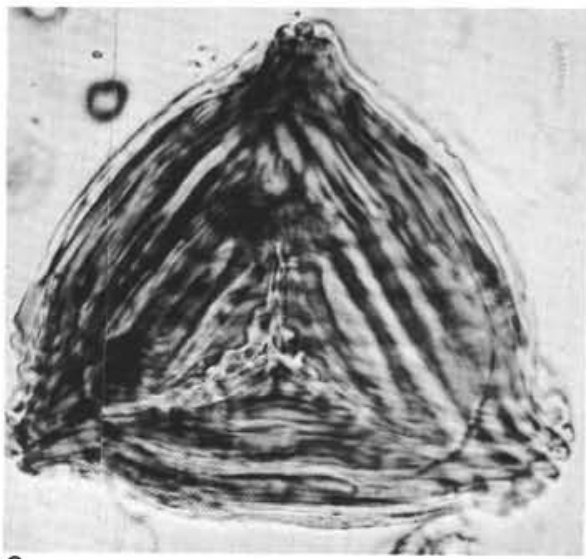

3

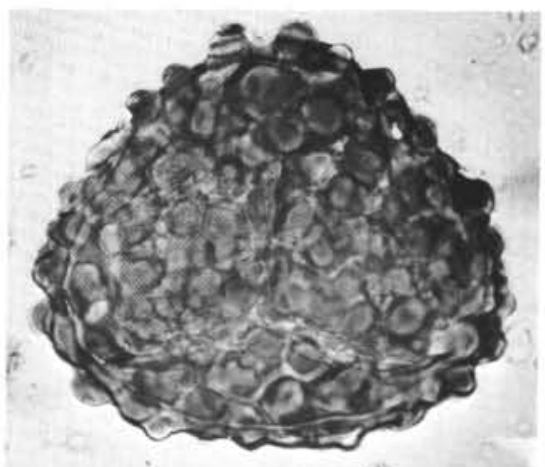

6

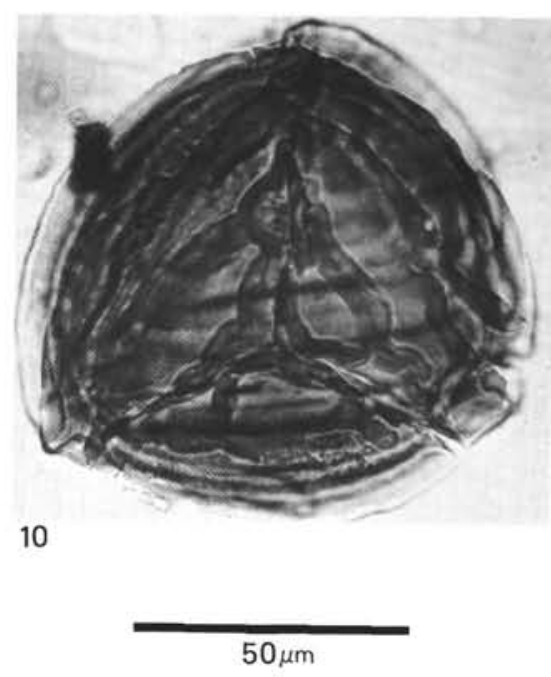

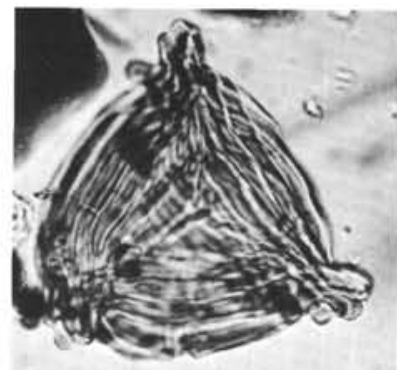

13

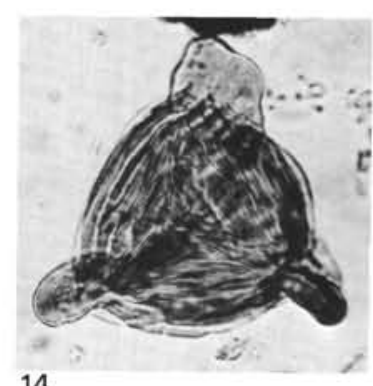

14 